\title{
Virtual Trainer for Mobile Augmented Reality Based Electrical Lighting Installation
}

\author{
https://doi.org/10.3991/ijim.v14i07.12397 \\ M. Khairudin $\left.{ }^{凶}\right)$, M. Iskandar, Istanto.W. Djatmiko \\ Universitas Negeri Yogyakarta, Indonesia \\ moh_khairudineuny.ac.id \\ Irdayanti Mat Nashir \\ Universiti Pendidikan Sultan Idris, Perak, Malaysia
}

\begin{abstract}
Virtual trainer of mobile Augmented Reality (AR)-based Electrical Lighting Installation is a technology that can be utilized as a substitute for either conventional or modern virtual-based trainers. It can be used anywhere and anytime with the help of an Android-based smartphone device. As a learning aid, the development of AR technology helps users to interact directly with lighting installation components for residential use in a virtual form that has been designed to resemble the actual form. In developing the application, several procedures must be performed before it is ready to use. The result of the study is an application which provides a 3D simulation of single-phase installation to help students understand the electrical components for residential lighting installation using the AR mobile technology.
\end{abstract}

Keywords - Virtual trainer, augmented reality, mobile, electrical lighting installation.

\section{Introduction}

Virtual trainer serves as a practical means for understanding the characteristics and working systems of the real world. In this study, it is used as a learning aid to study the components of electrical lighting installation. Virtual trainer is the answer to a common problem among formal or informal educational institutions, namely the lack of learning facilities and infrastructure for students. To produce good graduates, the school requires learning equipment that is always updated with the latest technology. However, the budget limitation often becomes the main cause for the lack of practical aids that support students in the teaching and learning process. With the fulfillment of facilities and infrastructure, students are expected to achieve competencies in accordance with the learning objectives.

Nowadays, smartphones have become a basic necessity for everyone. Smartphone users are able to communicate and interact with each other despite time and space. The most widely used Operating System (OS) on smartphone devices is Android. In addition to having many applications that can be downloaded for free, the Android OS 
is the choice of application among developers because of its easy-to-use supporting facilities.

Other forms of technology that have increasingly become popular today are Augmented Reality (AR) and Virtual Reality (VR). The use of virtual technology is widely developed in applications and gaming devices. AR and VR have been highly recommended for game lovers. AR technology is technology supported by a device that can display a 3-dimensional visual form (3D) that looks like the real world by utilizing the camera features on smartphone devices. One of the AR technologies that boomed in early 2016 and are still popular among users today was introduced through a game developed by Niantic called Pokemon Go. This virtual-based game has successfully attracted over eleven million Android users to download it on the Google Play Store.

In regard to the popularity and wide use of smartphones among the youth, it is necessary to have technology that combines smartphone and learning technology to increase the competency of students. The use of AR as a learning media can not only help streamline the expenditure of procurement of practical equipment, but also allow students to learn more easily as the components are designed with an assembly system in detail.

Electrical lighting installation is a basic competency that must be possessed by practitioners in the field of electrical installation engineering. To understand the basic electrical lighting installation, practitioners must master the basic knowledge of electricity, especially the introduction of electrical components, basic electrical installation, and knowledge of electrical circuit drawings and symbols.

Schramm [1] states that in the learning process, it is not enough just to have textbooks or still pictures as a learning medium as it may cause the class to be dull. Teachers must develop their own learning media that is not only appropriate and attracts the attention of students, but also economical, effective and easy to develop. The teacher as a facilitator must be able to provide facilities that enable the success of the learning process.

According to Persson et al. [2], the concept of mobile learning has five characteristics, consisting of probability, accessibility, personalization, connectivity, and the ability to increase learning motivation. These characteristics can be seen in the mobile-based learning media for lighting installation in this study.

On the other hand, Triatmaja et al. [3] argue that smartphones with Android OS have become a necessity for everyone to communicate regardless space and time. As an inseparable part of human needs, it is no wonder that the world of education also requires the use of smartphones that are student-friendly. The fact that many students now own and use smartphones to communicate suggests that it is important to develop mobile-based learning media that can increase the effectiveness of learning.

Dengzhe Ma et al. [4] describe AR as the main technology for virtual engineering. $\mathrm{AR}$ is the basis for functional virtual prototyping. The AR technology enables developers to analyze the forms and functional behavior of future products in an immersive and interactive virtual environment. The application of AR technology greatly improves communication in product design and production development. This is be- 
cause AR technology helps identify and avoid design errors in the early stages of the development process, while saving time and money at the same time.

A study by Jaya [5] found that laboratories and practice equipment in vocational education are essential to provide practical knowledge for students. Conventional laboratories are available but limited due to a large number of students. The main disadvantages of laboratories in general are expensive equipment and instruments. As a solution to this problem, this study developed a virtual laboratory to help students improve their practical skills in the field of household electrical power installations.

Odeh et al. [6] explain that the advantages of virtual media are that it is easy to use, helps students to easily understand the concept, readily available at all times, and covers all the theories. Moreover, it guarantees a safe environment and comfortable place, advances new areas of expertise, is encouraged by the group collaboration model, in addition to providing more time to experiment.

Based on a study by Dyrberg et al. [7] the advantages of AR can serve as a solution to the problems in learning practice due to its great resemblance to the actual physical environment. In comparison to physical environment, virtual environment can save budget, is safer for students, and makes the practice more developed. Finally, the interaction in virtual environment provides a distinct experience which can increase student motivation, assignment grades, and self-efficacy.

Ogungbenro et al. [8] describe some of the advantages of using emulators in digital techniques, namely the original look, feel and behavior of digital objects retained. Additionally, although the initial capital on emulator production is greater, other expenditures will be more efficient. Another advantage is reducing the time of laboratory use. Many emulators are well developed and licensed. Emulator can be used in a variety of device systems and physical needs. By using an emulator system, the costs and practice time can be reduced. The majority of emulator system has a large data memory and can provide many simulated electronic components.

Khairudin et al. [9] found that virtual technology is very helpful for students in learning digital techniques in vocational high schools. The problem in digital engineering learning is that it requires a lot of space and equipment; hence, a virtual media with VR technology is made as a solution for students in learning digital techniques using virtual reality technology.

Meanwhile, Agus Suryanto et al. [10] developed mobile AR technology to address the problem in learning a new piece of equipment. In a conventional learning, the teacher only explains lathe in front of the class so that not all students fully understand the characteristics of the machine. This problem is solved by introducing lathe with the help of AR technology as the learning media.

Erfy Ismail et al. [11] explained that in the development of learning media for AR technology in Vocational High School, it is necessary to create a learning atmosphere that can attract students' learning interest, improve student visualization, and reduce the cognitive burden experienced by students. In addition, the teaching and learning process is more interesting because the teacher's style of using theory and practice simultaneously. The use of AR in education not only helps building a safe teaching and learning environment, but also enhances students' visualization abstractly, which helps them when conducting experimental tests. Iskandar [12] reported that in the 
delivery of learning materials for electrical installation techniques that require a lot of tools and materials, learning media serves as a ready-to-use, attractive, and affordable alternative for students.

This study presents the development of AR-based application system design as the learning media for electrical lighting installation techniques in residential homes. Through the application, users can learn about all the materials on the subject. The AR technology allows them to see various electrical components used in residential electrical installations in real terms through smartphones. The materials are packaged in the form of a modern semi-game application, and include the overview, the components, and the instruction on how to do single-phase lighting installation in a simple residential house. With the latest technology, the minimum users, in this case students, will have their own time to try and understand the material available on learning media independently, even without the teacher's assistance.

\section{Designing a Virtual Trainer for The Subject of Electrical Lighting Installation}

This study produced a virtual laboratory for the subject of electrical lighting installation. Learning trainers were compiled using AR technology. The Electrical Lighting Installation Trainer was made with an interface and learning features designed to resemble the actual form of components and work systems in the real world. The ARassisted Electrical Lighting Installation Trainer had four main menus, namely the instruction menu, material menu, AR camera menu and profile menu.

The user manual menu consisted of the functions of the buttons and how to operate the learning media for electrical lighting installation. The instruction was in the form of text and images be used in operating the learning media. In addition, there was a hint menu which was equipped with markers that served to give an explanation in detail starting from the installation process of learning media applications on Android smartphones and other things that need to be considered so that the application was able to run normally. In the material menu, the user was provided with the introduction of some basic components that were commonly used or applied in residential lighting installations.

The explanation of the components in the material menu was only limited to the functions and types of lighting installation components which could provide a little description of basic knowledge for users of the work system of simple lighting installations in residential homes. The component explanation in the material menu included kWh meter.

The AR camera menu was the main menu in the application. In the AR camera menu, the user was directly connected to the previously programmed vuforia camera to detect an image or to perform an action. The vuforia camera in this learning media application removed the 3D object dimension of the electrical lighting installation component. Meanwhile, on the profile menu, there was information on learning media for the installation of developed electrical lighting and the profile of the learning me- 
dia instructor. To understand the work system of virtual trainers in residential electrical installation techniques, Figure 1 is presented below.

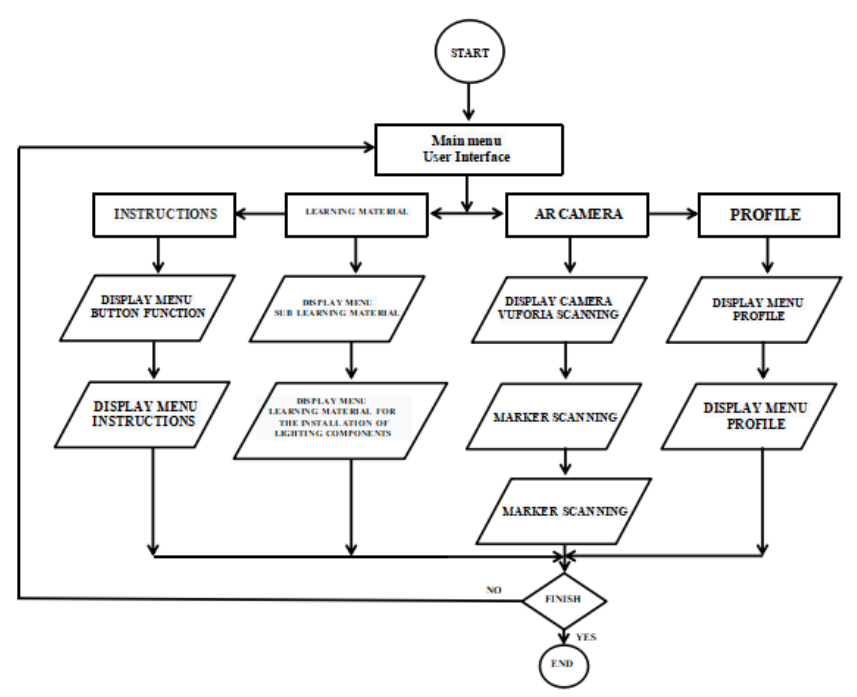

Fig. 1. Flowchart of Virtual Trainer System

Figure 1 presents a flowchart of a virtual electric lighting installation trainer work system. When the virtual trainer application ran, it displayed four main menus on the smartphone screen. The menus presented in Figure 2 below are on manual, AR camera, and profile.

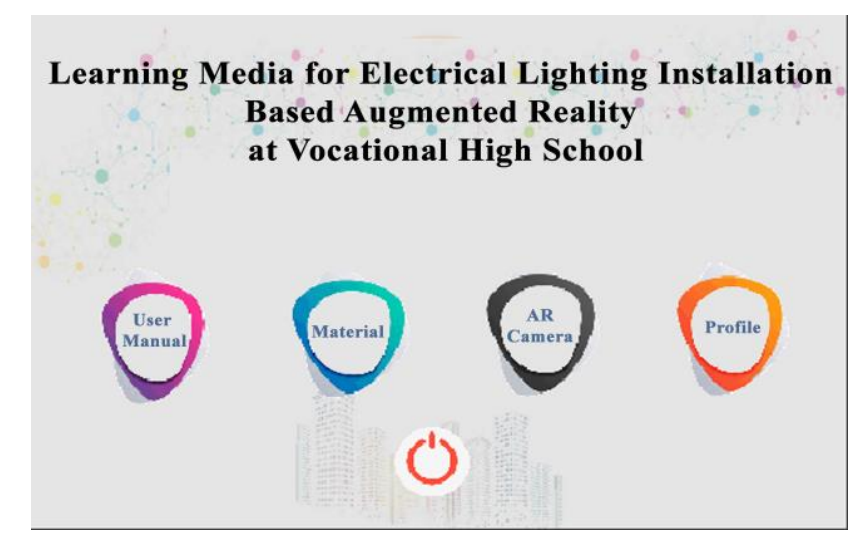

Fig. 2. Window for Main Menu

In the instructions menu, procedures for using and explanations of some feature functions were shown by buttons. Other supporting devices were used when running the application. The hint menu was displayed in a certain window. Then, there were 
sub-menus and eight material sub-menus to explain the materials related to some lighting installation components used in residential electrical lighting installations. The material menu consisted of a submenu, namely fittings and switches, sockets, lights, Miniature Circuit Breaker (MCB), cables, plugs, connection boxes, and kWh meters. The design of the sub-material menu is shown in Figure 3.

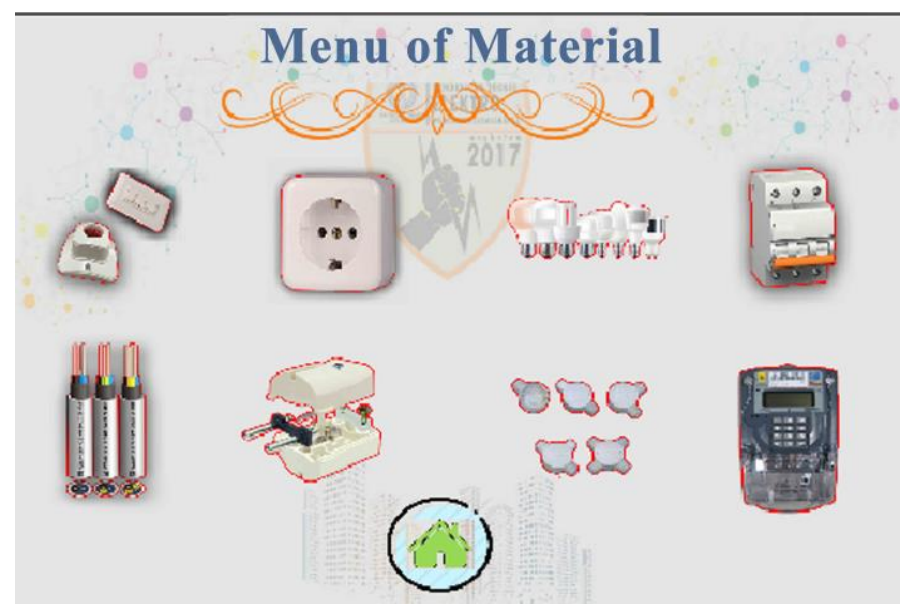

Fig. 3. Material Menu

In the AR camera menu, the user was directly connected to a scanner camera called the vuforia camera. This camera had previously been programmed to mark images called markers in this application.

If the markers were given a program to display a $3 \mathrm{D}$ object, then during the scanning process the marker would display a 3D object matching the object that had been programmed. As an example, if an object was named a switch, the marker image that had been programmed would display the switch object when the marker scanning process was performed. The last menu on the main menu of this lighting installation application was the profile menu containing information on the application being developed and the application developer's profile.

\section{Results and Discussions}

Regarding Figure 2 that shows the display of learning media for electric lighting installations, there are four main menus, namely user manual, material, AR camera, and profile. The lists of manual and instruction for using the learning media are presented in the earlier window. Instructions with animations are also available to help users operate the media easily.

As explained in Figure 1, there are eight sub-menus in the material menu, each of which explains the material related to the existing sub-menus i.e. fitting and switch, sockets, lights, Miniature Circuit Breaker (MCB), cables, plugs, connection boxes and 
$\mathrm{kWh}$ meters. In the material explanation, the function of components installed in residential lighting installations is presented.

A single switch can be presented in the AR Camera menu display using AR technology. Users are only asked to point the smartphone towards the marker or direct the marker towards the smartphone to access the material until the component and component assembly appear on the smartphone screen. When the process of scanning object is done, 3-D objects are displayed on the screen, but to display the objects, previously programmed markers should be in place.

Besides, to display 3-D objects, the lighting installation virtual trainer application displays a video assembly of the lighting installation component. In the video, there are fragments of the split assembly components to show the characteristics of the lighting installation components.

The devices needed in the preparation of the AR virtual trainer are Android Smartphones, Laptops/PCs, Unity 3D, 3D Blanders, SolidWorks, Adobe Photoshop CS 6 and markers. The virtual electric lighting installation trainer was developed using the Unity 3D application from a laptop and PC. The learning media used AR technology running on Android OS-based smartphones. The anchor and the components in the media are designed using the SolidWorks application with the extension .fbx file and the 3D Blender application with the extension. To design the display, Adobe Photoshop CS 6 applications are used. The markers are designed using Adobe Photoshop CS 6 applications generated from Building use various applications so that the final results of the application program could be accessed on an android smartphone with apk. extension.

Some of the features in the AR learning media for electrical installation techniques are interactive touch and visual control. This visual control feature allows users to carry out commands through the visual codes displayed.

Interactive Touch will appear when touched on the smartphone screen. In the AR camera menu directly connected to the smartphone camera feature, components are displayed in $3 \mathrm{D}$ objects when the scanning process is done. Components appearing in the smartphone screen can then be moved to see all sides in the component design section. Thus, the user may know the characteristics of components appearing in accordance with the original form of components in the real world. In this study, the AR media can show the media working system displaying components in the material menu.

The visual Control and Commands provide the sensations of learning like playing a smartphone game. The visual and command features in the learning media for electric lighting installations are intentionally developed using AR technology. By utilizing the touch sensor on the LCD screen of the smartphone, the electrical components are designed so that they resemble their original form and show more-detailed displays. The display of visual control settings and commands can be seen in Figure 4. 


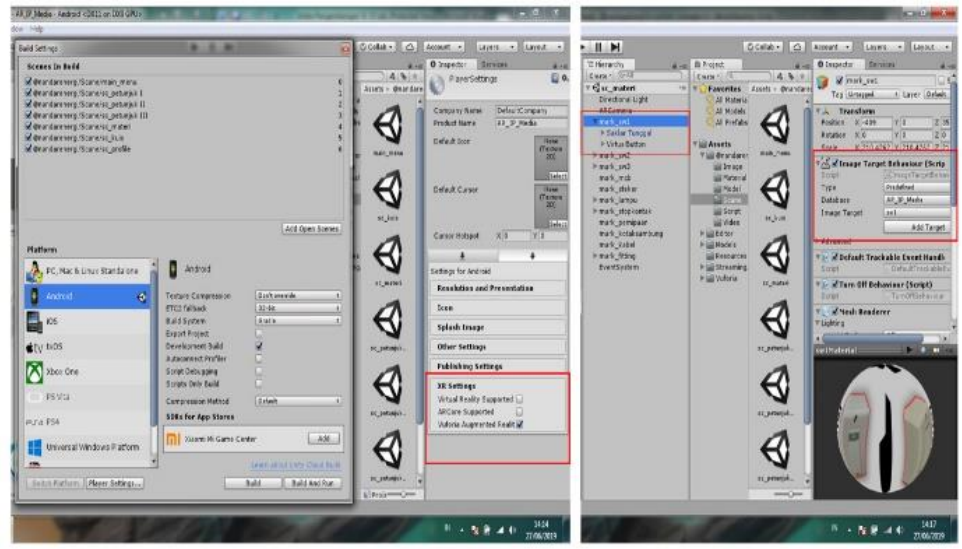

Fig. 4. Setting for Visual Control and Command

Figure 5 shows the algorithm for visual control and commands when 3D objects appear on the smartphone screen. 3D objects can be moved to all X-Y-Z axials as a means of observing objects.

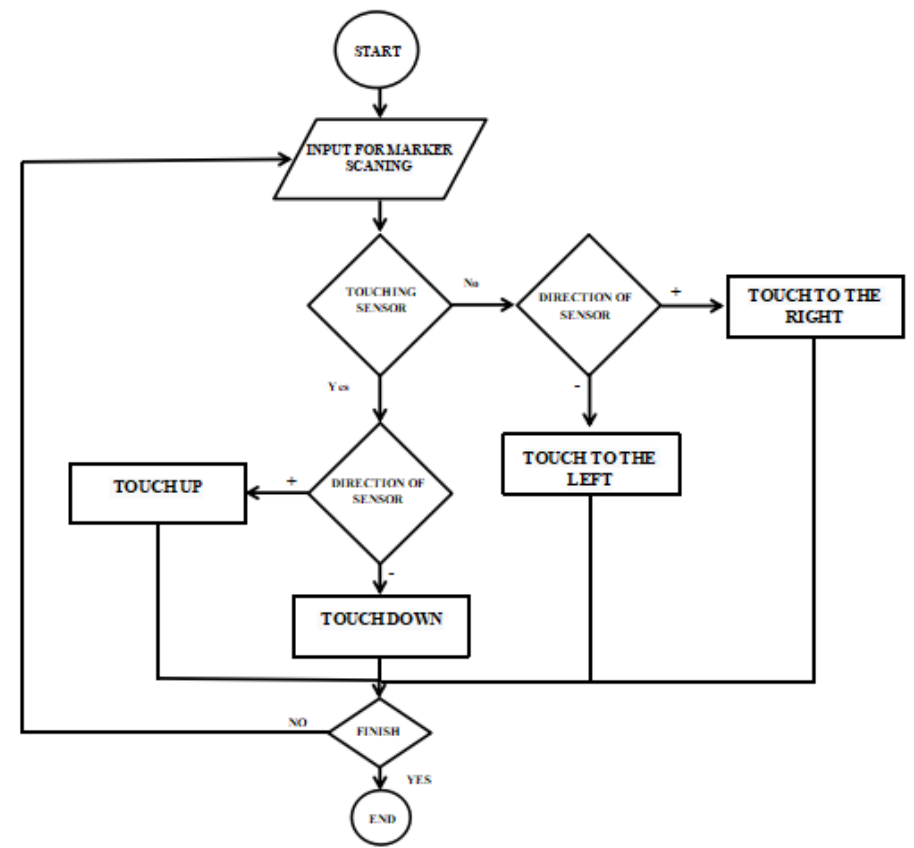

Fig. 5. Flowchart of Visual Control 
Visual control was needed to give an interactive impression on the virtual trainer application when interacting with objects appearing when scanning. In the scanning marking process, the objects can move left, right, up, down. The direction of the axis may be $\mathrm{x}, \mathrm{y}$, or $\mathrm{z}$. In the $\mathrm{z}$ direction, the objects automatically rotate.

When markers are scanned, 3-D objects are automatically displayed in accordance with the program that is determined on the markers. Figure 6 displays a 3-D object when scanning the marker on the AR camera menu. To display objects on the smartphone screen through this virtual trainer application, the user simply needs to point to the vuforia camera at the AR menu. Thus, when scanning in the right angle, 3-D objects are scanned according to the marker images.

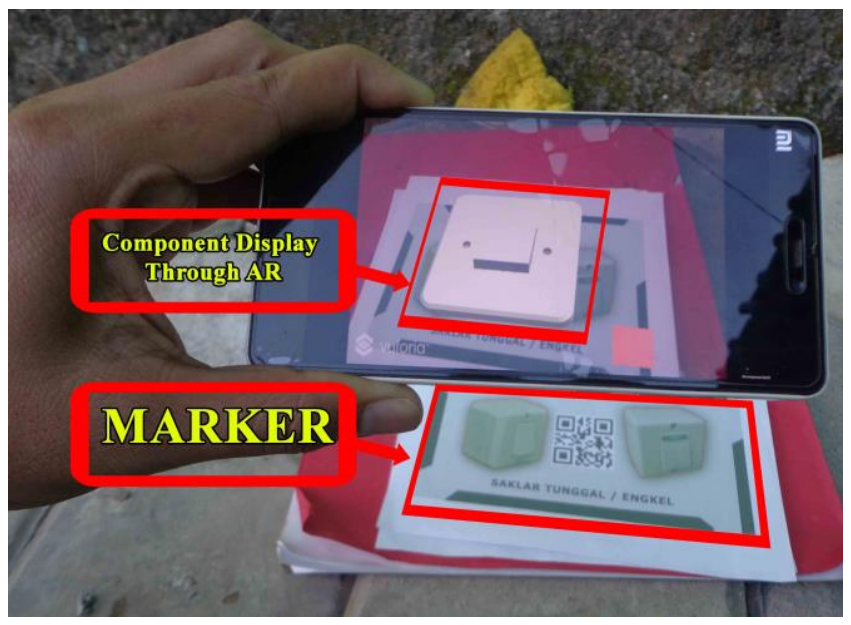

Fig. 6. Marker Scanning Process Using Smartphone for the switch

To display the form of components in AR technology, there are several forms of markers developed to adjust the shape of the original components. Components displayed in the learning media for this electrical lighting installation are commonly used in household lighting installations i.e. KWH Meters, Miniature Circuit Breakers (MCB), Cables, Sockets, Switches, Switches Double, Switches Three Gang, Lights, Pipes, Fittings, Plugs, and Piping Electrical Lighting Installations. Those components are shown in the forms of original components and animation of household lighting work systems.

Each displayed component is equipped with an assembly video. This is intended to improve students or users' knowledge of the characteristics of the lighting components in accordance with their actual forms.

In the electrical lighting installation, pipeline simulation is shown in animation in which the presented drawings become a reference for lighting installation to be prepared. In this simulation, the installation position, functions, and working system of each component are shown. The display in this pipeline simulation starts from the electrical power source from the State Electricity Company (PLN) entering the KWH Meter to the loads commonly used in simple house buildings. 


\section{Conclusion}

AR technology-assisted electric lighting installation trainer was developed with the aim of introducing an alternative technology in the field of education. Using the technology, interesting and fun learning for students is created by not neglecting the elements of learning and competencies that the students want to achieve in learning. With the AR application on electric lighting installation media, students can learn anytime and anywhere because of what they need to learn within the reach of their hands. Electrical lighting installation trainers also help educators make learning time more efficient because in theoretical subjects, students are able to describe the electrical components, characteristics, functions and also lighting installations in the household without being in the workshop. This learning media for electrical lighting installations provides knowledge about the basic lighting installations in the form of an introduction to lighting installation components, introduction to the characteristics of lighting installation components, selection of the layout of household lighting installation components, adjustment of technical drawings to the form of installation as in the real world.

\section{$5 \quad$ References}

[1] Schramm, 1984. Media Besar Media Kecil, Alat dan Teknologi untuk Pengajaran, Seri Pustaka Teknologi Pendidikan No. 5. IKIP Semarang.

[2] Persson, V. \& Nouri, J. (2018) A Systematic Review of Second Language Learning with Mobile Technologies. International Journal of Emerging Technologies in Learning. Vol. 13 (2), 53-61. https://doi.org/10.3991/ijet.v13i02.8094

[3] Triatmaja, A. K. \& Khairudin, M. (2018). Study on Skill Improve/ment of -Digital Electronics Using Virtual Laboratorium With Mobile Virtual Reality. Journal of Physics: Conference Series. Vol. 1140, https://doi.org/10.1088/1742-6596/1140/1/012021

[4] Dengzhe Ma., Jurgen Gausemeier., Xiumin Fan., \& Michael Grafe. (2011). Virtual Reality \& Augmented Reality in Industry. The 2nd Sino-German Workshop. Shanghai Jiao Tong University Press, ISBN 978-7-313-06426-4. Springer Heidebery Dordrecht London New York, ISBN 978-3-642-17375-2, e-ISBN 978-3-642-17376-9 https://doi.org/10.1007/978$\underline{3-642-17376-9}$

[5] Jaya, H. (2010). Laboratorium Virtual Mata Kuliah Praktikum Elektronika Digital: Jurusan Pendidikan Teknik Elektronika Fakultas Teknik Universitas Negeri Makassar. Jurnal Elektronika Telekomunikasi \& Computer, Vol.4(2). 699-710. https://doi.org/10.36232/pendi dikan.v6i2.36

[6] Odeh, S., Shanab, S, A., \& Anabtawi, M. (2015). Augmented Reality Internet Labs versus its Traditional and Virtual Equivalence. International Journal of Emerging Technologies in Learning. Vol. 10 (Issue 3), 4-9. https://doi.org/10.3991/ijet.v10i3.4354

[7] Dyrberg, N, R., Treusch, A, H., \& Wiegand, C. (2016). Virtual laboratories in science education: Students Motivation and Experiences in Two Tertiary Biology Courses. Journal of Biological Education. Vol.51 (4), 358-374. https://doi.org/10.1080/00219266.2016.1257 $\underline{498}$

[8] Ogungbenro, O, U., Chukwudebe, G, A., Opara, F, K., \& Ezeh, G, N. (2017). Design and Implementation of Logic Gate Emulator. 3rd International Conference on Electro Technol- 
ogy for National Development, 7-10 November 2017, Owerri, Nigeria https://doi.org/10. 1109/nigercon.2017.8281936

[9] Khairudin M., Triatmaja A.K., Istanto W.J., Azman M.N.A., (2018). Mobile Virtual Reality to Develop a Virtual Laboratorium for the Subject of Digital Enggineering. International Journal of Interactive Mobile Technologies. Vol 13, No 04 (2019) https://doi.org/10.3991/ ijim.v13i04.10522

[10] Agus Suryanto., Diah Ayu Kusumawati., \& Ibrahim M. H. Sanhoury. (2018). Development of Augmented Reality Technology Based Learning Media Of Lathe Machines. Jurnal Pendidikan Teknologi dan Kejuruan, Vol. 24, No. 1, May 2018, pp. 32-38. ISSN:08544735, DOI: 10.21831/jptk.v24i1.18245 https://doi.org/10.24114/jptk.v20i1

[11] Mohd Erfy Ismail., Mohd Hasril Amiruddin., Pipit Utami., Irwan Mahazir Ismail., Moh. Khairudin., Badraningsih Lastariwati., \& Nopadon Maneetien. (2018). The effect of an augmented reality teaching kit on visualization, cognitive load and teaching styles. Jurnal Pendidikan Teknologi dan Kejuruan, Vol. 24, No. 2, October 2018, 178-184. ISSN:08544735, DOI: 10.21831/jptk. v24i2.20031. https://doi.org/10.21831/jptk.v23i2.12296

[12] Iskandar Muhamad., Khairudin M. (2019). Learning Media of Electric Lighting Installation Based on Mobile Augmented Reality. 2nd International Conference on Electrical, Electronics, Informatics, and Vocational Education, 14-15 September 2019, Yogyakarta, Indonesia. https://doi.org/10.1088/1742-6596/1413/1/012024

\section{Authors}

Moh. Khairudin received his bachelor from Universitas Negeri YogyakartaIndonesia at the department of electrical engineering in 2002. He graduated from Institute Teknologi Sepuluh Nopember (ITS)-Indonesia with M.Eng. in control electrical engineering in 2006 and completed his $\mathrm{PhD}$ in control electrical engineering in 2012, from Universiti Teknologi Malaysia, Johor, Malaysia. His research field is in the area of Flexible Manipulator, Robotics and Automation, Robust Control and Intelligent Control System.

M Iskandar is a master student at the department of electrical engineering education, Post graduate school of Universitas Negeri Yogyakarta-Indonesia. His master thesis is entitled virtual laboratory for digital engineering.

Istanto Wahyu Djatmiko received his bachelor degree from Universitas Negeri Yogyakarta-Indonesia at the department of electrical engineering. His master and doctoral degrees were from the department of vocational education and training in Universitas Negeri Yogyakarta-Indonesia. Now he is the head department of master program of electrical engineering education-Universitas Negeri Yogyakarta. His research field is in the area of human resources development for the teacher enhancement.

Irdayanti Mat Nashir. Senior Lecturer, $\mathrm{PhD}$ at the Faculty of Technical and Vocational, Universiti Pendidikan Sultan Idris. He is the author, co-author and editor of several papers on TVET Leadership Model: as well as published more than 20 scientific papers. Research interests focus on the study of TVET Leadership Model.

Article submitted 2019-11-16. Resubmitted 2019-12-14. Final acceptance 2019-12-14. Final version published as submitted by the authors. 